\title{
Economic and environmental impacts of pasture nutrient management
}

\author{
EDWARD OSEI, PHILIP W. GASSMAN, LARRY M. HAUCK, SUSAN NEITSCH, RON D. JONES, JAN MCNITT, \\ AND HEATHER JONES
}

Authors are Senior Research Economist, Texas Institute for Applied Environmental Research (TIAER), Tarleton State University, Stephenville, Tex, 76402, Research Agricultural Engineer, Center for Agricultural and Rural Development, Iowa State University, Ames, Iowa 50011, Assistant Director, TIAER, Research Asssociate, Spatial Sciences Laboratory - Texas A\&M University, College Station, Tex 77843, Director, TIAER, Worker Advocate, State of Maine, Portland, Maine 04101, and Senior Research Assistant, TIAER.

\begin{abstract}
Highly intensive stocking of dairy cattle on continuously grazed pasture coupled with liberal applications of commercial fertilizer can lead to increased losses of agricultural nutrients, which is a concern for water quality of receiving lakes and surface water resources. Integrated economic-environmental model simulations performed for the Lake Fork Reservoir Watershed in northeast Texas indicate that appropriate pasture nutrient management including stocking density adjustments and more efficient commercial fertilizer use could lead to significant reductions in nutrient losses. Soluble and organic $P$ losses were predicted to decline by 54 and $13 \%$ relative to baseline conditions when manure $P$ was assumed totally plant available (Low $P$ scenario). The soluble and organic $P$ loss reductions declined to 33 and $7 \%$ when only inorganic $P$ was assumed plant available (High $\mathbf{P}$ scenario). Simulation of an $\mathrm{N}$-based manure management plan resulted in the smallest predicted soluble and organic $P$ loss reductions of 18 and $3 \%$. Nitrogen loss predictions ranged from a $7 \%$ decline to a $1 \%$ increase for the 3 scenarios as compared to the baseline. The High $P$ and Low $P$ scenarios resulted in estimated aggregate profit reductions of 6 and $18 \%$ relative to the baseline. These profit declines occurred because the dairies had to acquire additional pasture land to accommodate the expanded area required for the P-based scenarios. In contrast, the $\mathbf{N}$-based stocking density and nutrient management scenario resulted in an aggregate profit increase of $3 \%$ across all dairies. Variations in economic impacts were also predicted across farm sizes.
\end{abstract}

Key Words: Stocking density, manure, nutrient losses, nitrogen, phosphorus, economics

Concerns over adverse water quality impacts associated with livestock production have increased dramatically over the past few decades. Much of this concern is due to concentration of livestock production in relatively small areas or specific watersheds, resulting in problems such as increased nitrogen $(\mathrm{N})$ and

The authors acknowledge support from the U.S. Environmental Protection Agency (USEPA) which provided funding for the project under Contract No. CR 820384-02-7. The views expressed in this paper are not necessarily those of the USEPA.

Manuscript accepted 13 Jul. 02.

\section{Resumen}

La carga altamente intensiva de ganado lechero en praderas apacentadas continuamente, acompañado con aplicaciones abundantes de fertilizante comercial pueden conducir a un aumento de perdida de los nutrientes agrícolas, lo cual es una preocupación para la calidad del agua de los lagos receptores y los recursos de agua superficial. Simulaciones de un modelo integral ambiental-económico realizadas para la cuenca hidrológica del Lago Fork en el noreste de Texas indican que el manejo apropiado de los nutrientes de la pradera, incluyendo ajustes en la densidad de carga animal y el uso de fertilizantes comerciales más eficientes, pudiera conducir a reducciones significantes en las perdidas de nutrientes. Se predijo que las perdidas de $P$ soluble $y$ orgánico disminuirían en 54 y $13 \%$ en relación a las condiciones iniciales, esto cuando se asumio que el $\mathbf{P}$ del estiércol era totalmente disponible para las plantas (escenario de baja disponibilidad de $\mathbf{P}$ ). La reducción de las perdidas de $\mathbf{P}$ soluble y orgánico disminuyó a 33 y $7 \%$ cuando se asumió que solo $P$ inorgánico estaba disponible para las plantas (escenario de alta disponibilidad de P). La simulación de un plan de manejo de estiércol basado en $\mathbf{N}$ resulto en las reducciones más pequeñas de perdida de $P$ soluble e inorgánico, 18 y $3 \%$. Las predicciones de perdida de $\mathrm{N}$ variaron de $7 \%$ de disminución a $1 \%$ de incremento, esto para los 3 esenarios y comparando con el contenido inicial. Los escenarios de $P$ alto y bajo resultaron en reducciones estimadas de la ganancia agregada del 6 y $18 \%$ en relación al contenido inicial. Estas disminuciones de la ganancia ocurrió porque las lecherías tienen que adquirir terrenos de pradera adicionales para proveer el área expandida necesaria para los escenarios basados en $P$. En contraste, el escenario de la densidad de carga animal y el manejo de nutrientes basados en $\mathbf{N}$ resulto en un incremento de la ganancia agregada del $3 \%$ a través de todas las lecherías. Variaciones en el impacto económico fueron también predichas a través de todos los tamaños de granjas.

phosphorus (P) loads in surface water from land-applied manure. Various studies have been performed to evaluate environmental problems related to livestock production (e.g. Dietz and Hoogervorst 1991 - the Netherlands, Hamilton and Sims 1995 the southern portion of Delaware, Warrick and Leavenworth 1996 - the Neuse River Watershed in North Carolina, and McFarland and Hauck 1999 - the Upper North Bosque River Watershed (UNBRW) in north central Texas). 
A National Pilot Project (NPP) on Livestock and the Environment was initiated in 1992 to help provide solutions regarding environmental problems associated with livestock manure management (Jones et al. 1993). A major development of the NPP is the Comprehensive Economic and Environmental Optimization Tool - Livestock and Poultry (CEEOT-LP), an integrated modeling system designed to generate economic and environmental indicators for different scenarios encompassing alternative manure processing technologies, variations in rates and modes of landapplied manure and commercial fertilizer, and other best management practices. The initial application of the modeling system was for a range of policy scenarios focused on manure management in the upper north Bosque river watershed as described by Pratt et al. (1997) and Osei et al. (2000b).

To evaluate implications of various management practices on dairy pasture operations, the modeling system was next applied to pasture-based dairy operations located in the Lake Fork Reservoir Watershed (LFRW) in northeast Texas (McNitt et al. 1999). In livestock agriculture, most nonpoint sources of excessive nitrogen and phosphorus loads have been attributed to confined animal feeding operations whereas pasture-based operations have received relatively minor attention. However, Bottcher et al. (1995) estimated that significant nutrient losses would occur from grazed pastures with high animal densities in the Lake Okeechobee region of Florida, based on various monitoring results and unpublished computer simulations. In a review of several studies, Correll (1996) found that pastures managed with high levels of exogenous nutrients and high animal densities could seriously impact the quality of surface waters. Belsky et al. (1999), in an extensive review, also report that water quality impacts from livestock grazing have been documented across the United States. The objective of this study was to evaluate the economic and environmental impacts of alternative pasture stocking densities and appropriate commercial fertilizer supplementation based on conditions prevailing in the Lake Fork reservoir watershed.

In light of the existing literature, it was hypothesized that low stocking densities and reduced commercial fertilizer supplementation on pastures would lead to a decline in nutrient losses. However, these would also have economic implications to producers due to expected per hectare yield declines and the need to obtain larger pasture area for grazing livestock. To obtain quantitative estimates of these impacts, the following questions were posed:

1. How much change in $\mathrm{N}$ and $\mathrm{P}$ losses would result from typically suggested pasture nutrient management standards (including stocking density adjustments and commercial fertilizer reductions)?

2. What economic impacts to producers are associated with these standards?

\section{The Lake Fork Reservoir Watershed}

The Lake Fork Reservoir Watershed (LFRW) drains portions of Hopkins, Hunt, Rains, and Wood counties in northeast Texas (Fig. 1). The 127,000 ha watershed

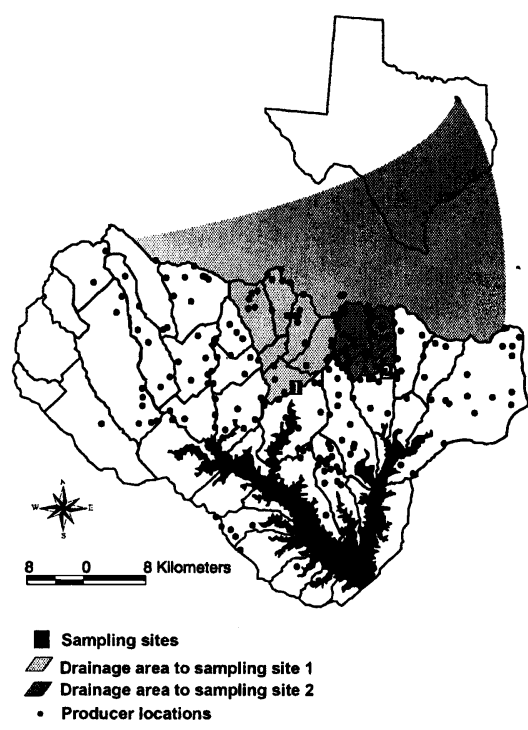

Fig. 1. The Lake Fork Reservoir Watershed (LFRW) with locations of dairy operations, sampling sites, SWAT subbasins, and the reservoir.

contains an 11,210 ha lake that is used primarily for fishing and water supply. Since the early 1990s substantial work done as part of the Lake Fork Creek Hydrologic Unit Area (LFCHUA) project, a cooperative interagency project initiated in the study area, has resulted in improvements in water quality (LFCHUA 1995). As part of the Hydrologic Unit Area project, water quality measurements were taken in the watershed, which showed elevated levels of $\mathrm{N}$ and $\mathrm{P}$ in some of the tributaries of the Lake Fork Reservoir (LFCHUA 1995). The key problems encountered and addressed within the Hydrologic Unit Area project involved pasture denudation and over-fertilization of pastures from manure and commercial fertilizer sources.

A total of 205 dairies with a combined herd size of 26,855 cows were located in the watershed at the time of this study. The majority of the dairies lie within Hopkins County, the second highest milkproducing county in Texas. The vast majority of the dairies in the watershed utilize pasture-based production systems that require confinement of the milking cows only when they are milked. Pasture management consisting of open access grazing $(\mathrm{OAG})$ is used in which cows continuously graze bermuda grass overseeded with winter annuals, primarily winter wheat, rye grass and/or clover. Because pastures are not managed intensively, significant denudation was observed on these grazing operations prior to initiation of the Hydrologic Unit Area project. Pasture management practices that eliminate denudation were shown by McNitt et al. (1999) to generally result in significant reductions in nutrient losses for the watershed. Pasture-based beef production and cow-calf operations that raise calves for slaughter or for replacement of milking cows on dairies are also prevalent in the watershed. Manure deposition and commercial fertilizer applications were both sources of nutrients to the improved pastures used by the beef and dairy operations.

Approximately $71 \%$ of the watershed land area was used for pasture in 1996, with about $44 \%$ classified as improved and the remaining 27\% defined as unimproved (Ewer and Easterling 1998). Forest and brush cover almost $8 \%$ of the remaining land area; less than $2 \%$ of the land area was devoted to cropland. Most of the land is characterized by deep, loamy to sandy soils that are slowly permeable and well drained. Average annual temperature and precipitation are $10^{\circ} \mathrm{C}$ and $1,118 \mathrm{~mm}$.

\section{Model Framework and Simulation Methodology}

Alternative stocking density scenarios for the watershed were performed in a whole-farm manner through an interface of the economic and environmental components within the modeling system (Fig. 2). The Farm-level Economic Model (FEM) is a representative farm model (Osei et al. 2000a) that is used to simulate farm-level economic impacts in response to different policy scenarios. The environmental component consists of 2 models, the field-level Agricultural Policy/Environmental eXtender (APEX) model (Williams et al. 


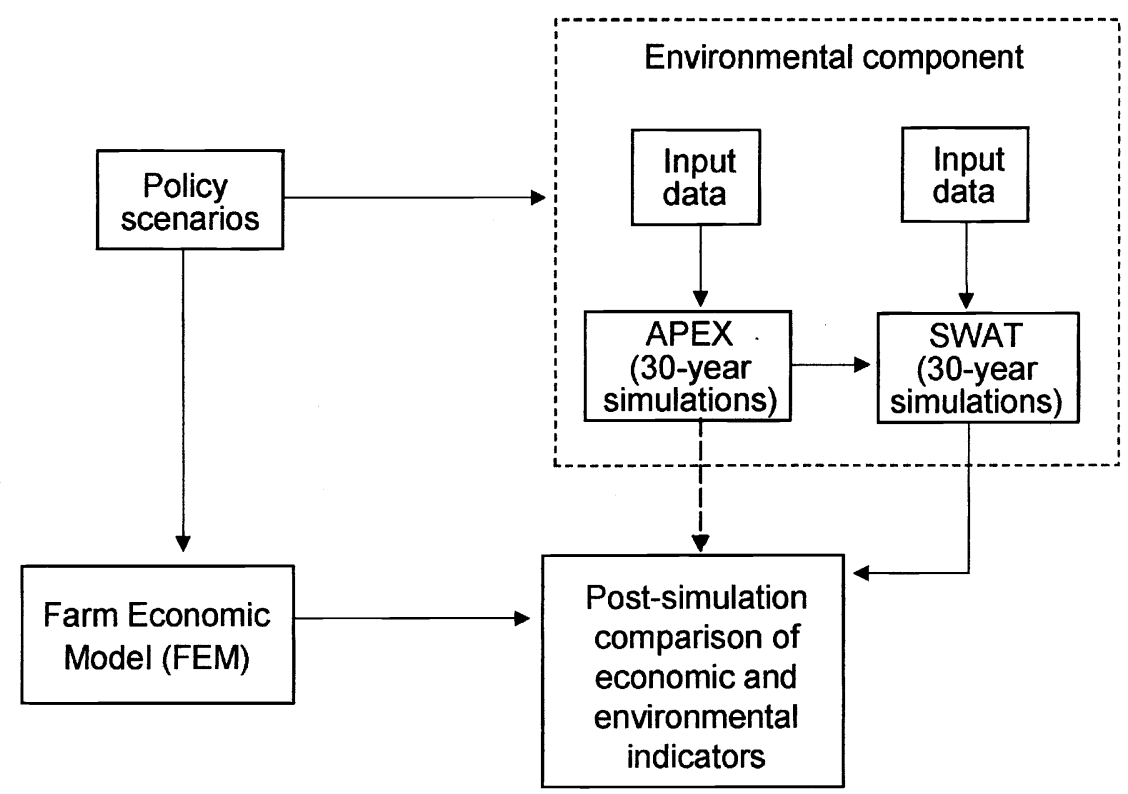

Fig. 2. Schematic of key data flows between models used in the Comprehensive Economic and Environmental Optimization Tool-Livestock and Poultry (CEEOT-LP) modeling system.
1995, 2000) and the watershed-level Soil and Water Assessment Tool (SWAT) model (Arnold et al. 1998). The APEX model is a modified version of the Erosion Productivity Impact Calculator (EPIC) model (Williams 1990, 1995) that is used in the modeling system to simulate alternative management scenarios such as variations in manure and fertilizer application agement practices (BMPs). Edge-of-field sediment and nutrient losses simulated in APEX, coupled with losses simulated in the SWAT model from other land uses, are routed in SWAT through the stream system to the watershed outlet. Watershedlevel indicators from SWAT were used in this study to assess the environmental impacts of the simulated scenarios. However, APEX edge-of-field indicators can also be used in conjunction with, or instead of, the SWAT indicators (Fig. 2).

The economic model operates on annual time step and can be executed for extendgories of input data required to simulate a farm in the economic model include type of livestock system, manure management methods, cropping systems, facilities and equipment, field characteristics, and other external factors. Economic outputs generated by the model include total revenue, total cost, net returns, livestock rations, sales, costs of individual production components (crop and livestock, fertilizer, labor, etc.), debt payment, and owner's equity. rates, and adoption of structural best maned periods of 30 years or more. Key cate-
Economic model simulations were performed for 4 representative dairy operations, 1 for each of 4 size categories constructed to help evaluate the impacts of the scenarios across dairies of different size (Table 1). Dairy farm categories and representative sizes were based on data listing the financial profile of dairies in Hopkins County, Tex. (McDonald 1995). Representative sizes (Table 1) were 95 cows for very small dairies ( $<100$ cows), 178 cows for small dairies (101 to 200 cows), 275 cows for medium sized dairies (201 to 300 cows), and 556 cows for large dairies (> 300 cows). Land area for each dairy was assumed to consist of both pasture and hayland (Table 1). Other charac- teristics related to cull cows, heifers, and land area for the representative dairies are also listed in Table 1.

The edge-of-field model operates on a daily time step and can be applied for a wide range of soil, landscape, climate, crop rotation, and management practice combinations. It can be executed for a single field or used for a wide range of multifield configurations including whole farms, small watersheds, or filter strip impacts on nutrient losses from waste application fields. The main edge-of-field model components are weather, hydrology, soil temperature, erosion-sedimentation, nutrient cycling, tillage, management practices, crop management and growth, and pesticide and nutrient fate and transport. Choice of simulated cropping system, manure and/or fertilizer nutrient characteristics, tillage practices, soil layer properties, and other characteristics are input for each simulated subarea. Key outputs include crop yields, edge-of-field nutrient and sediment losses, and other water and nutrient balance indicators.

All 205 dairies were simulated directly in the edge-of-field model instead of using the economic model representative farms. Dairies were categorized into one of the 4 groups listed in Table 1, based on herd size. Specific pasture and hay field areas could not be obtained for the majority of dairies; however, mean pasture and hay field areas were provided by the Texas State Soil and Water Conservation Board (TSSWCB) for each of the 4 dairy categories. Thus, the pasture and hay field areas simulated for each dairy were determined as a function of the mean herd size, pasture areas, and hay field areas for the respective category. Further description of
Table 1. Herd sizes and other characteristics of the representative watershed dairies simulated in the economic model.

\begin{tabular}{lcrrr}
\hline \hline & Very Small & Small & Medium & Large \\
\hline Herd size range & $<100$ & $101-200$ & $201-300$ & $>300$ \\
Herd size (lactating and dry cows) & 95 & 178 & 275 & 556 \\
Cows culled annually & 24 & 46 & 82 & 160 \\
Replacement heifers purchased annually & 0 & 15 & 15 & 172 \\
Replacement heifers raised annually & 30 & 40 & 84 & 5 \\
Replacement heifers and calves on farm & 60 & 80 & 168 & 10 \\
Total land area per cow (ha) & 0.34 & 0.34 & 0.34 & 0.27 \\
Hay and cropland area per cow (ha) & 0.06 & 0.05 & 0.06 & 0.08 \\
Heifer pasture area per cow (ha) & 0.13 & 0.09 & 0.13 & 0.00 \\
Lactating and dry cow area per cow (ha) & 0.15 & 0.20 & 0.16 & 0.18 \\
Baseline (current) pasture stocking density $\left(\mathrm{cows} \mathrm{ha}^{-1}\right)$ & 6.4 & 5.2 & 6.4 & 5.4 \\
Coastal/wheat agronomic N requirement $\left(\mathrm{kg} \mathrm{ha}^{-1}\right)$ & 336 & 336 & 336 & 336 \\
Coastal/wheat agronomic P requirement $\left(\mathrm{kg} \mathrm{ha}^{-1}\right)$ & 54 & 54 & 54 & 54 \\
Average milk yield (kg/cow/year) & 6717 & 6822 & 7916 & 7602 \\
\hline
\end{tabular}

Source: The information in this table was based on extensive data from the study area. 
the watershed edge-of-field model methodology is given in Osei et al. (2000a).

The Soil and Water Assessment Tool was developed to simulate continuoustime streamflow with a high level of spatial detail by allowing the division of a watershed or river basin into grid cells or sub-watersheds. The model operates on a daily time step and is designed to evaluate management effects on water quality, sediment, and agricultural chemical yield in large, ungaged basins. The major components of the watershed-scale model include hydrology, weather, sedimentation, soil temperature, crop growth, nutrients, pesticides, and agricultural management. The Soil and Water Assessment Tool inputs and outputs are similar to those used in the edge-of-field model.

The remaining land that was not simulated in the edge-of-field model was simulated in the watershed-scale model, and this constituted the majority of the watershed land area. Unimproved pasture was simulated as rangeland in the watershedscale model. Improved pasture, woodland, urban, and the reservoir were the other simulated land use categories. The rangeland and improved pasture were assumed grazed by beef cattle according to the stocking rates described by Bailey and Riggs (1996). Simulated N and P application rates via manure deposition and inorganic fertilizer on pastures and rangeland grazed by beef cattle were also based on values reported by Bailey and Riggs (1996). Point source N and P loadings to tributaries of the Lake Fork Reservoir from 4 waste treatment facilities were accounted for in the watershed model. The total $\mathrm{N}$ and $\mathrm{P}$ loads calculated for the baseline and alternative scenarios were the sum of $\mathrm{N}$ and $\mathrm{P}$ loadings contributed by 7 different tributaries that drain into the reservoir.

\section{Edge-of-field and Economic Model assumptions}

It was estimated that a typical milking cow in the watershed produces $127 \mathrm{~kg} \mathrm{~N}$ and $27 \mathrm{~kg} \mathrm{P}$ annually in manure based on ASAE standards (ASAE 1995). These estimates were based on the mean plus 1 standard deviation of the ASAE values, following customary practice in formulating dairy waste management plans in the study area. Assuming that the percentage of manure deposited on pasture is directly proportional to amount of time spent there, about $88 \%$ of manure nutrient is deposited on pasture and the remainder is collected from the milking parlor and applied on fields designated for liquid waste. This assumption is based on extensive data in the study area which indicates that cows are confined for milking 3 hours each day and turned out on pasture for the remainder of the day (TNRCC various years).

Appropriate manure application rates or stocking densities are based on plant available manure nutrients rather than total manure nutrient production because of various losses and transformations that occur prior to plant uptake. Two adjustments were incorporated in the simulation of manure nitrogen deposited on pasture in order to estimate the proportion that was available for plant uptake. First, it was assumed that $20 \%$ of the manure $\mathrm{N}$ would volatilize from the soil surface, based on permitting guidelines used by the Texas Natural Resource Conservation Commission (TRNCC) as described by Flowers et al. (1998). Second, only $50 \%$ of the remaining manure $\mathrm{N}$ was assumed to be plant available within the first year after direct deposition on pasture, again following local guidelines (Flowers et al. 1998).

Subsequent mineralization of the $\mathrm{N}$ applied in the manure will release additional plant available $\mathrm{N}$ within the soil in the years following deposition (USDA 1979, Flowers et al. 1998). Ideally, this additional $\mathrm{N}$ should be factored into decisions as to the amount of manure $\mathrm{N}$ that would be applied to the same pastures in future depositions. However, a conservative assumption was made that it would be impracticable for producers to keep track of such processes due to inadequate soil testing or irregular use of soil test results. Thus it was assumed that only $50 \%$ of manure $\mathrm{N}$ remaining in the soil profile after volatilization would be considered plant available in every year. No losses were assumed for manure phosphorus or commercial fertilizer nutrients.

Heifers were included in the economic model simulations mainly for cost accounting purposes. The percentage of the overall watershed manure load that would be attributed to the heifer portions of the dairy herds is about $20 \%$. Heifer grazing was not simulated in the edge-offield model, and none of the scenarios discussed in this paper had any impact on heifer pasture area. However, the heifer manure load was indirectly accounted for in the watershed-scale model, because all of the remaining watershed pasture land (including the heifer pasture areas) was assumed to receive beef cattle manure deposition. Although the manure characteristics and stocking rates differ between the 2 species, simulated beef cattle manure depositions accounted for the heifer herd manure loads.

Baseline stocking densities assumed for the dairies varied depending on pasture area available and whether or not a significant portion of pasture was devoted to raising replacement heifers (Table 1). Most large dairies devote a greater portion of land to hay fields than smaller dairies, but they also raise fewer replacement heifers. Baseline lactating and dry cow stocking density was estimated by first subtracting hay area from the total land area, then allocating 0.2 ha of pasture for each replacement heifer raised on the farm. The remaining area was divided by the number of lactating and dry cows to obtain baseline stocking densities (Table 1). The number of replacement heifers raised was based on typical culling practices, death losses, and replacement heifer purchases recorded in dairy farm financial profiles for Hopkins County, Tex. (McDonald 1995) and from communications with watershed experts. The resulting average baseline stocking density across the 4 dairy sizes was about 5.7 cows per hectare (Table 2). This stocking density was corroborated by various experts in the study area who had indicated during independent consultations that stocking densities on dairy pasture in the watershed range from 5 to 7.5 cows per hectare.

The stocking rate of 5.7 cows per hectare results in a total manure $\mathrm{N}$ rate of $624 \mathrm{~kg} \mathrm{ha}^{-1}$ and a corresponding manure plant available nitrogen rate of $250 \mathrm{~kg} \mathrm{ha}^{-1}$ (Table 2). The associated total manure $\mathrm{P}$ and mineral $P$ rates were 135 and $88 \mathrm{~kg}$ $\mathrm{ha}^{-1}$. It was further assumed for the baseline that producers applied about $247 \mathrm{~kg} \mathrm{~N}$ and about $146 \mathrm{~kg} \mathrm{P}_{2} \mathrm{O}_{5}$ (59 kg P) per hectare of pasture each year (Table 2), based again on the judgement of local experts. These application rates were also corroborated by fertilizer cost estimates in dairy farm financial profiles (McDonald $1995)$ as well as fertilizer sales figures for the 4-county region (Office of the State Chemist 1996). Thus the total plant available nitrogen going on pasture each year from manure and commercial fertilizer sources was about 1.5 times the agronomic rate (Table 2).

\section{Additional Economic Model Assumptions}

The scenarios simulated entail various rates of manure and commercial fertilizer nutrients on pasture. To account effectively for economic impacts of these scenar- 
ios, some yield adjustments were made in the economic model to reflect different forage yield responses to manure and commercial fertilizer nutrients. Yield responses were estimated using nitrogen rather than phosphorus application rates. Using information from the study area, it was estimated that commercial fertilizer $\mathrm{N}$ response for Coastal Bermuda grass was $40 \mathrm{~kg}$ dry matter yield/kg N. After further calculations, manure nitrogen yield response was determined to be $24 \mathrm{~kg}$ dry matter yield per $\mathrm{kg}$ of manure plant available nitrogen for Bermuda grass. For winter wheat pasture, about $10 \mathrm{~kg}$ dry matter yield per $\mathrm{kg}$ of nitrogen was assumed for commercial fertilizer $\mathrm{N}$ as well as plant available manure N. Lower yield responses are generally anticipated from manure deposited on pasture than from commercial fertilizer because: (1) manure is deposited unevenly, and (2) trampling of pasture grasses by cattle under open access grazing conditions also stifles forage growth. However, the same winter wheat yield responses were used for manure and commercial fertilizer because the only available information did not suggest higher wheat yield responses from commercial fertilizer (Brown, B. 1997. Personal communication. Texas A\&M University System Extension. Sulphur Springs, Tex.).

In spite of these pasture forage yield adjustments, stocking densities and fertilizer application rates were based on baseline yields to reflect realistic producer behavior since it is impracticable that most producers would estimate yield adjustments in advance and modify application rates accordingly. It was important to mimic actual producer behavior to obtain good estimates of the scenario impacts.

Economic modeling accounted for greater forage availability and uptake by cows when total pasture forage production is increased. However, the model did not assume a proportional decrease in feed costs. This is because larger pasture forage production means that cattle would consume more coastal and wheat forage, necessitating adjustments in purchase of supplemental feed for the herd. The model includes a comprehensive livestock nutrition component that mimics the way producers (and their nutritionists) determine livestock rations. Based on typical milk yields in the study area (ranging from about $6,700 \mathrm{~kg}$ to $7,900 \mathrm{~kg}$ per cow annually for the 4 dairy groups), over $50 \%$ of dry matter intake of lactating cows is from supplemental feed, which is provided in feed troughs placed on the pasture. In extreme cases of overabundant pasture and hay forage production some forage raised on hay fields might be sold.

A two-step General Algebraic Modeling System (GAMS) process (Brooke et al. 1992) was used to estimate purchased feed cost and how much forage, if any, is sold. First, a feed cost minimization process was performed assuming that any unused forage from hay fields or pasture would be sold at a "price" (shadow value) lower than the selling price. During the second step of the process, the unused forage was assumed sold at the selling price rather than the shadow value with adjustments made for marketing expenses. For the watershed simulations, the shadow value for pasture forage was estimated to be $\$ 0$ per ton based on model calibrations. In other words, dairy producers in the watershed would use as much pasture and hay field forage as they can on the dairy, and only sell what the cows cannot consume.

\section{Alternative Pasture Nutrient Management Scenarios}

The first pasture nutrient management alternative simulated for the watershed was performed by setting the stocking density to 7.7 cows ha ${ }^{-1}$, resulting in a manure plant available nitrogen rate of $336 \mathrm{~kg} \mathrm{ha}^{-1}$ that is equal to the nitrogen agronomic requirement of the forage (Table 2). Thus it was assumed that the $\mathrm{N}$ needs of the pasture forage were completely met by manure $\mathrm{N}$, eliminating the need for supplemental $\mathrm{N}$ fertilizer applications. The $\mathrm{N}$ rate scenario also resulted in correspondingly higher inorganic $\mathrm{P}$ and total manure $\mathrm{P}$ application rates that were 2.2 and 3.3 times greater than the agro-

Table 2. Key characteristics of alternative pasture management scenarios ${ }^{\mathrm{a}}$.

\begin{tabular}{|c|c|c|c|c|}
\hline Scenario & Baseline & $\mathrm{N}$ & High P & Low $P$ \\
\hline Average stocking density (cows ha ${ }^{-1}$ ) & 5.7 & 7.7 & 3.5 & 2.2 \\
\hline Commercial fertilizer $\mathrm{N}$ rate $\left(\mathrm{kg} \mathrm{ha}^{-1}\right)$ & 247 & 0 & 182 & 235 \\
\hline Commercial fertilizer $\mathrm{P}$ rate $\left(\mathrm{kg} \mathrm{ha}^{-1}\right)$ & 59 & 0 & 0 & 0 \\
\hline Manure PAN ${ }^{\mathrm{b}}$ rate $\left(\mathrm{kg} \mathrm{ha}^{-1}\right)$ & 250 & 336 & 155 & 100 \\
\hline Total manure $\mathrm{N}$ rate $\left(\mathrm{kg} \mathrm{ha}^{-1}\right)$ & 625 & 841 & 386 & 251 \\
\hline Manure inorganic- $\mathrm{P}$ rate $\left(\mathrm{kg} \mathrm{ha}^{-1}\right)$ & 88 & 118 & 54 & 35 \\
\hline Total manure $\mathrm{P}$ rate $\left(\mathrm{kg} \mathrm{ha}^{-1}\right)$ & 135 & 182 & 84 & 54 \\
\hline Estimated coastal yield ( $\mathrm{kg}$ dry matter $\left.\mathrm{ha}^{-1}\right)$ & 6,390 & 3,767 & 4,372 & 4,562 \\
\hline Estimated wheat yield (kg dry matter ha $\left.{ }^{-1}\right)$ & 3,020 & 1,872 & 2,063 & 2,119 \\
\hline Ratio of total PAN to agronomic $\mathrm{N}$ requirement & 1.5 & 1.0 & 1.0 & 1.0 \\
\hline Ratio of total $\mathrm{N}$ to agronomic $\mathrm{N}$ requirement & 2.6 & 2.5 & 1.7 & 1.4 \\
\hline Ratio of total inorganic- $\mathrm{P}$ to agronomic $\mathrm{P}$ requirement & 2.7 & 2.2 & 1.0 & 0.7 \\
\hline Ratio of total $\mathrm{P}$ to agronomic $\mathrm{P}$ requirement & 3.6 & 3.3 & 1.5 & 1.0 \\
\hline
\end{tabular}

Source: The data in this table was computed from extensive information from the Lake Fork reservoir watershed. ${ }^{a}$ All fertilizer and manure application rates simulated on an annual basis

${ }^{\mathrm{b}} \mathrm{PAN}=$ plant available nitrogen nomic $\mathrm{P}$ rate of the crop (Table 2). Again, supplemental $\mathrm{P}$ fertilizer was not required for this scenario, because the crop uptake requirements for $\mathrm{P}$ were more than satisfied by manure $P$.

Two alternative P-based stocking density scenarios were also simulated for the watershed, defined as "High P" and "Low $\mathrm{P}$ ". These scenarios reflected prevailing opinions about how P-based nutrient management plans should be designed. The High $\mathrm{P}$ stocking density scenario assumes that the organic (particulate) component of manure $\mathrm{P}$ is not readily available for plant uptake resulting in the inorganic $\mathrm{P}$ portion in the manure being deposited at a rate equivalent to forage agronomic $P$ requirements. The calculated High $P$ stocking rate of 3.5 cows ha ${ }^{-1}$ results in manure inorganic $\mathrm{P}$ and total $\mathrm{P}$ deposition rates of 54 and $84 \mathrm{~kg} \mathrm{ha}^{-1}$, and associated manure plant available nitrogen and total $\mathrm{N}$ application rates of 155 and $386 \mathrm{~kg} \mathrm{ha}^{-1}$ (Table 2). Due to the disparity between the N/P ratio of manure nutrients and that of forage required at a rate of $182 \mathrm{~kg} \mathrm{ha}^{-1}$ to meet the forage agronomic $\mathrm{N}$ requirements.

The Low P option assumes a stocking density and commercial nutrient application such that manure total $\mathrm{P}$ supplies all forage $\mathrm{P}$ needs. The resulting stocking rate was estimated to be 2.2 cows ha ${ }^{-1}$, with corresponding manure inorganic and total $\mathrm{P}$ deposition rates of 35 and $54 \mathrm{~kg} \mathrm{ha}^{-1}$ (Table 2). In this case, an even higher commercial fertilizer $\mathrm{N}$ rate of $235 \mathrm{~kg} \mathrm{ha}^{-1}$ was simulated to meet the agronomic $\mathrm{N}$ requirements of the pasture forage. The Low P scenario entails the least stocking density and consequently the greatest pasture area requirement. requirements, commercial fertilizer $\mathrm{N}$ was 
Table 3. Mean values of key measured and simulated water quality indicators for the Lake Fork reservoir watershed.

\begin{tabular}{lcccc}
\hline \hline Indicator & Site $^{1}$ & Number of observations $^{2}$ & Measured $^{3}$ & Simulated $^{3}$ \\
\hline Flow $\left(\mathrm{m}^{3} \mathrm{sec}^{-1}\right)$ & 1 & 133 & 0.67 & 0.73 \\
$\mathrm{NO}_{3}\left(\mathrm{mg} \mathrm{liter}^{-1}\right)$ & 2 & 31 & 2.46 & 2.93 \\
Soluble P $\left(\mathrm{mg} \mathrm{liter}^{-1}\right)$ & 2 & 32 & 0.27 & 0.44 \\
Total P $\left(\mathrm{mg} \mathrm{liter}^{-1}\right)$ & 2 & 32 & 0.67 & 0.47 \\
Sediment $\left(\mathrm{mg} \mathrm{liter}^{-1}\right)$ & 2 & 30 & 112 & 64 \\
\hline
\end{tabular}

${ }^{1}$ See Figure 1 for location of sites 1 and 2.

${ }^{2}$ Monthly streamflow values were measured between September 1978 and September 1989 at site 1; nutrient and sediment measurements were performed between 12 April, 1994 and 11 November, 1996.

${ }^{3}$ Standard deviations reported for the observed and simulated flows were 0.875 and 0.703 ; standard deviations were not reported for the other indicators.
Consistent with scenario specifications, alternative stocking densities and associated supplemental commercial $\mathrm{N}$ fertilizer rates were simulated in the economic model for the lactating and dry cow pastures but not for the heifer pastures. Other assumptions were held at baseline specifications. The stocking density simulated for the $\mathrm{N}$ scenario is actually higher than the stocking density assumed for the baseline, which suggests that open access grazing operations in the watershed generally have adequate land to manage pasture nutrients according to forage $\mathrm{N}$ requirements. Forage $\mathrm{N}$ needs were being exceeded in the baseline because of commercial fertilizer rates used on pasture. Producers could, therefore, alternatively reduce commercial fertilizer rates, maintain current stocking densities, and still achieve reasonable pasture nutrient management regarding forage $\mathrm{N}$ requirements.

The P-based scenarios require additional pasture area that is currently not owned or farmed by dairies. Thus moving to the $\mathrm{P}$ scenarios may present logistical problems in some cases. Based on land availability and farming practices in the study area, it was assumed that dairy producers would purchase rather than lease additional land when they need to increase pasture area beyond existing levels.

\section{Results and Discussions}

\section{Model Testing}

Testing of the environmental models for watershed baseline conditions built upon previous testing of the models for the Upper North Bosque River watershed, in which edge-of-field output was compared with flow, sediment, and nutrient runoff losses at the edge of 8 field plots (Flowers et al. 1996) and watershed-scale model output (that incorporated edge-of-field loadings) was compared with in-stream observations of flow, sediment, and nutri- ents (Saleh et al. 2000). Monitoring data available for the Lake Fork reservoir watershed was relatively sparse, consisting of in-stream flow measurements at 1 site and in-stream sediment and nutrient observations at 5 other sites ( 3 of which were only monitored for 9 days). Watershedscale model predictions, that included edge-of-field loadings from dairy pastures and hayfields, were compared with flow measurements at sampling site 1 (Fig. 1) for a 10-year period and with sediment and nutrient measurements at sampling site 2 (Fig. 1) for slightly more than 2.5 years (the site with the longest record of in-stream sediment and nutrient observations). Predicted mean values for flow and other indicators compared favorably with observed means (Table 3 ), with the greatest difference resulting for sediment which was underpredicted by $50 \%$. Further description of the model comparisons with measured data is provided by S. Neitsch, (1998. Unpublished research data,
Blackland Research Center, Temple, Tex.).

The economic model was also calibrated for the watershed using data pertaining to Hopkins County, which encompasses more than half of the watershed. Comparisons of simulated and actual values for some economic indicators are given in Table 4 . The results indicate that economic model estimates of various indicators were reasonably close to measured values. Calibration results are reflective of Hopkins County dairy conditions, rather than the entire watershed. Thus scenario baseline results differ somewhat, as expected, from the calibration output.

\section{Scenario Results}

Environmental model simulations were performed for 30 years using daily precipitation, maximum temperature, and minimum temperature data obtained for Sulphur Springs, Texas and other nearby weather stations. Other required weather inputs were generated internally in the environmental models.

Figure 3 shows watershed-scale 30-year average annual baseline loadings, and the resulting impacts of the 3 stocking density scenarios relative to the baseline, for key sediment and nutrient indicators. The cant reductions in nutrient losses are attainable under all 3 alternative scenarios relative to the baseline. With the exception of $\mathrm{N}$ losses for the Low $\mathrm{P}$ rate, adopting pasture nutrient management based on forage $\mathrm{N}$ or $\mathrm{P}$ needs results unambiguously in results indicate that moderate to signifi-

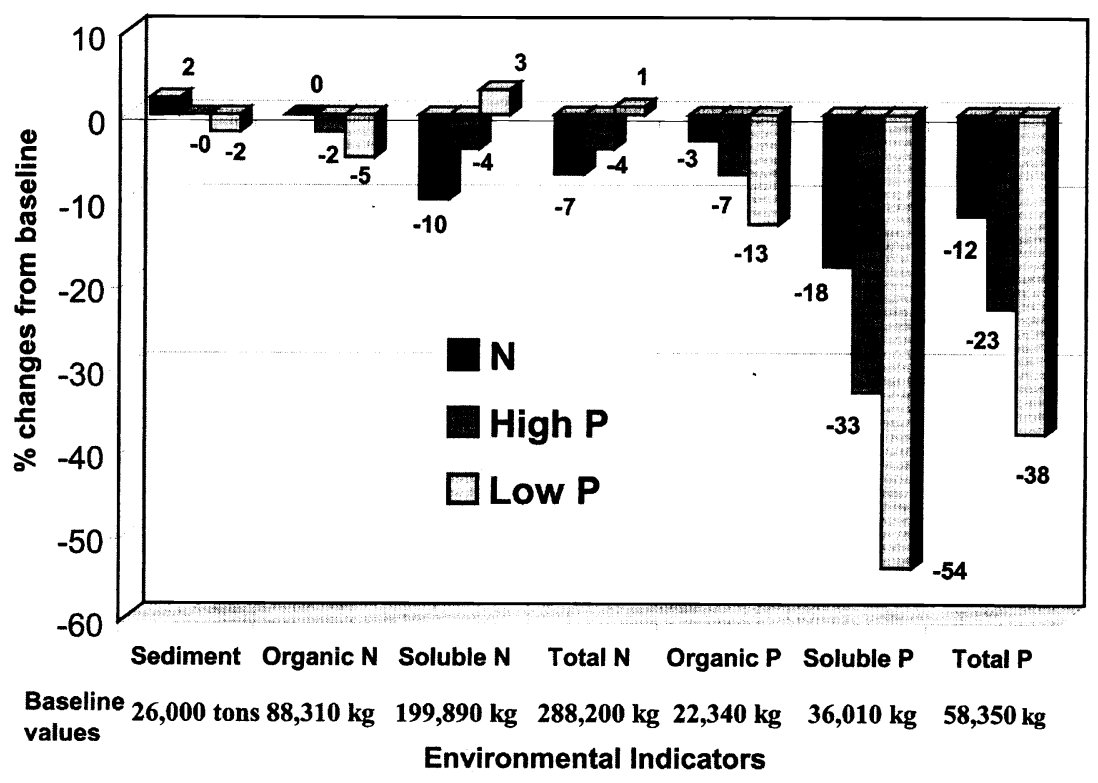

Fig. 3. Environmental impacts: \% changes from baseline values. 
Table 4. Comparison of measured and simulated values for various economic indicators.

\begin{tabular}{|c|c|c|c|c|c|}
\hline Indicator & $\begin{array}{l}\text { Measured vs. } \\
\text { Simulated }\end{array}$ & Very small & Small & Medium & Large \\
\hline Total Revenue & $\begin{array}{l}\text { Measured } \\
\text { Simulated }\end{array}$ & $\begin{array}{l}204,050 \\
204,050\end{array}$ & $\begin{array}{l}408,883 \\
408,883\end{array}$ & $\begin{array}{l}787,041 \\
787,041\end{array}$ & $\begin{array}{l}1,403,862 \\
1,403,862\end{array}$ \\
\hline Feed Cost & $\begin{array}{l}\text { Measured } \\
\text { Simulated }\end{array}$ & $\begin{array}{l}79,829 \\
76,249\end{array}$ & $\begin{array}{l}167,297 \\
159,737\end{array}$ & $\begin{array}{l}408,882 \\
397,559\end{array}$ & $\begin{array}{l}502,128 \\
482,347\end{array}$ \\
\hline Other Costs & $\begin{array}{l}\text { Measured } \\
\text { Simulated }\end{array}$ & $\begin{array}{l}84,205 \\
85,207\end{array}$ & $\begin{array}{l}173,801 \\
178,143\end{array}$ & $\begin{array}{l}278,343 \\
277,849\end{array}$ & $\begin{array}{l}663,787 \\
642,335\end{array}$ \\
\hline Total Costs & $\begin{array}{l}\text { Measured } \\
\text { Simulated }\end{array}$ & $\begin{array}{l}164,034 \\
161,455\end{array}$ & $\begin{array}{l}341,098 \\
337,880\end{array}$ & $\begin{array}{l}687,225 \\
675,408\end{array}$ & $\begin{array}{l}1,165,915 \\
1,124,681\end{array}$ \\
\hline Net Returns & $\begin{array}{l}\text { Measured } \\
\text { Simulated }\end{array}$ & $\begin{array}{l}40,016 \\
42,595\end{array}$ & $\begin{array}{l}67,785 \\
71,003\end{array}$ & $\begin{array}{r}99,816 \\
111,633\end{array}$ & $\begin{array}{l}237,947 \\
279,181\end{array}$ \\
\hline
\end{tabular}

improved water quality benefits. Because the current stocking density is between the $\mathrm{N}$ and High $\mathrm{P}$ stocking densities, this suggests that producers only need to apply commercial fertilizer at lower rates than they do now to obtain a 4 to $7 \%$ reduction in total $\mathrm{N}$ loads and 12 to $23 \%$ reduction in total $\mathrm{P}$ loads at the watershed level. Edge-of-field reductions from the dairy pastures would be even higher.

Economic impacts estimated using the economic model are shown in Figure 4, which shows baseline net returns to unpaid labor and management for each dairy group and at the aggregate watershed level, and the percentage changes in net returns that occur when the stocking density scenarios are imposed. The watershed aggregate impacts were obtained as a weighted sum of the individual dairy effects using the number of dairies in each group as the weighting factor. Results presented in Figure 4 indicate that most dairies can benefit financially by shrinking pasture sizes slightly to accommodate forage $\mathrm{N}$ requirements with plant available manure $\mathrm{N}$ only and eliminating all commercial fertilizer sources. At the watershed-level, dairy profits increase by almost $3 \%$ in response to the $\mathrm{N}$-based stocking density scenario.

Contrary to the N-based scenario, the Pbased pasture nutrient management alternatives are costly. The High and Low $\mathrm{P}$ alternatives would cost producers 6 and $18 \%$ of current profits in aggregate, respectively. Table 5 shows various cost components and other indicators for all scenarios. In spite of the expanded area, total fertilizer cost is lower for all dairies under the High $\mathrm{P}$ scenario relative to the baseline. On the other hand, notwithstanding the increased pasture area total feed cost is no less under the High P scenario than the baseline, primarily because total forage production is slightly less due to much lower per hectare forage yield. The available, whereas all of the land required when moving from the High P scenario to the Low P scenario has to be purchased. Furthermore, fertilizer costs are higher with the Low P option, and purchased feed costs do not decline in a manner proportionate with pasture forage consumption. The latter results from the assumption that dairy producers would strive to maintain milk yields, which imposes various constraints on feed ration formulation. Thus the Low P scenario results in significantly greater cost to dairy producers than the High P option.

Finally, the economic impacts across dairy size groups are also significant (Fig. 4 and Table 5). This result suggests that, where possible, it may be socially optimal to give producers some latitude in choosing a set of options that would enable them to meet environmental criteria in a performance-based program. This latitude would result in a substantial decrease in the cost of nutrient loss reduction due primarily to the beneficial impacts of accounting for spatial variability across the grazing operations.

\section{Cost-effectiveness estimates for $\mathbf{P}$ loss reduction}

All 3 alternative scenarios presented above reduce total $\mathrm{P}$ loads relative to the baseline. While the Low P alternative provides the best prospect for $\mathrm{P}$ loss reduction, it can also lead to an increase in soluble $\mathrm{N}$ loads. The choice among these scenarios may also depend upon costs to dairy producers. Cost effectiveness estimates provide a uniform basis for comparison in

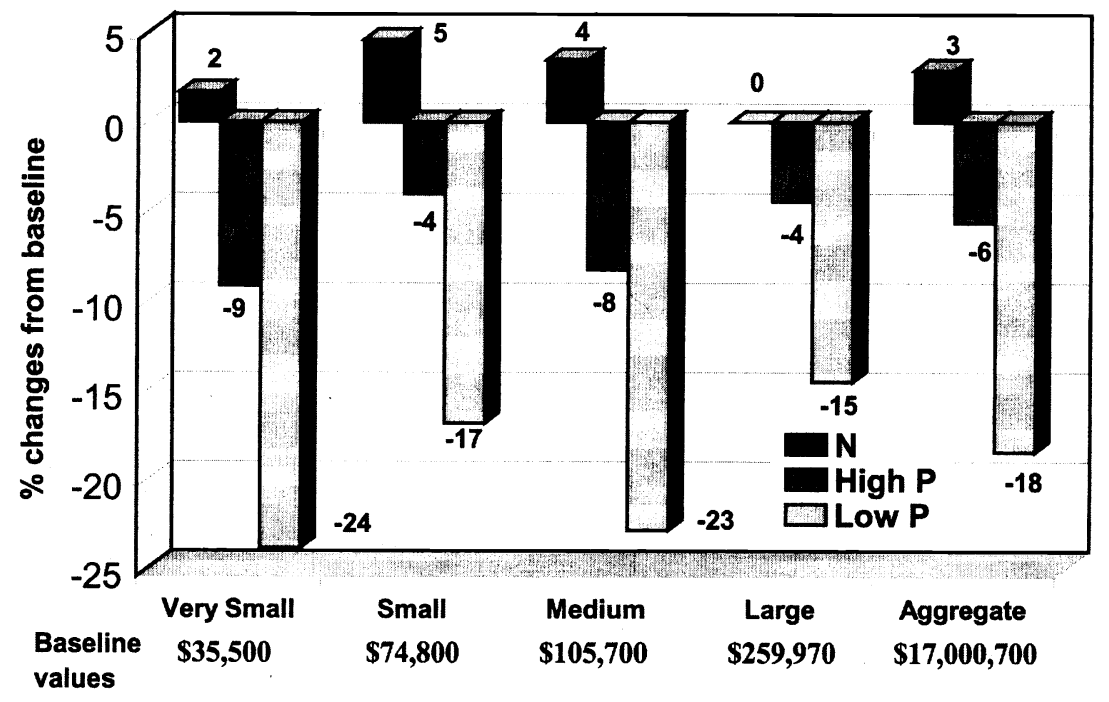

Fig. 4. Economic impacts: $\%$ changes in net returns from baseline values. 
Table 5. Summary land use and economic impacts of alternative pasture stocking densities ${ }^{\mathrm{a}}$.

\begin{tabular}{|c|c|c|c|c|c|c|c|c|c|c|c|c|c|}
\hline \multirow[b]{2}{*}{$\begin{array}{l}\text { Scenarios By } \\
\text { Farm Size }\end{array}$} & \multicolumn{3}{|c|}{----Land Area---- } & \multirow[b]{2}{*}{$\begin{array}{l}\text { Stocking } \\
\text { Density }\end{array}$} & \multirow{2}{*}{\multicolumn{2}{|c|}{$\begin{array}{c}\text { Additional Land } \\
\text { Purchased } \\
\text { Annual }\end{array}$}} & \multirow[b]{2}{*}{ Fertilizer } & \multicolumn{3}{|c|}{  } & \multirow[b]{2}{*}{$\begin{array}{l}\text { Fixed } \\
\text { Costs }\end{array}$} & \multirow[b]{2}{*}{ Revenue } & \multirow[b]{2}{*}{$\begin{array}{c}\text { Net } \\
\text { Returns }^{b}\end{array}$} \\
\hline & Total & Hay & Pasture & & & $\begin{array}{c}\text { Annual } \\
\text { Cost }\end{array}$ & & $\begin{array}{c}\text { Purchase } \\
\text { Feed }\end{array}$ & Other & Total & & & \\
\hline Very Small & \multicolumn{3}{|c|}{ 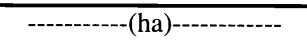 } & (cows/ha) & (ha) & $(\$ /$ farm) & & & \$/farm) --. & ----- & $(\$ /$ farm $)$ & $(\$ /$ farm $)$ & (\$/farm) \\
\hline Baseline & 32 & 5 & 27 & 6.4 & 0 & 0 & 9,200 & 69,000 & 62,200 & 140,500 & 30,900 & 206,900 & 35,500 \\
\hline $\mathrm{N}$ & 32 & 7 & 25 & 7.7 & 0 & 0 & 6,000 & 71,400 & 62,200 & 139,600 & 31,200 & 206,900 & 36,100 \\
\hline High P & 43 & 3 & 39 & 3.5 & 11 & 1,900 & 8,400 & 69,700 & 63,800 & 141,900 & 32,700 & 206,900 & 32,300 \\
\hline Low P & 57 & 3 & 54 & 2.2 & 26 & 4,400 & 12,700 & 65,300 & 66,300 & 144,300 & 35,500 & 206,900 & 27,100 \\
\hline \multicolumn{14}{|l|}{ Small } \\
\hline Baseline & 60 & 9 & 51 & 5.2 & 0 & 0 & 17,400 & 128,800 & 107,600 & 253,700 & 66,900 & 395,400 & 74,800 \\
\hline $\mathrm{N}$ & 60 & 20 & 40 & 7.7 & 0 & 0 & 12,400 & 128,300 & 108,200 & 248,900 & 68,300 & 395,400 & 78,200 \\
\hline High P & 74 & 6 & 67 & 3.5 & 14 & 2,300 & 13,900 & 131,200 & 109,500 & 254,600 & 69,000 & 395,400 & 71,800 \\
\hline Low P & 101 & 6 & 95 & 2.2 & 41 & 7,000 & 21,900 & 122,800 & 114,100 & 258,900 & 74,300 & 395,400 & 62,300 \\
\hline \multicolumn{14}{|l|}{ Medium } \\
\hline Baseline & 93 & 15 & 77 & 6.4 & 0 & 0 & 26,700 & 332,400 & 182,100 & 541,200 & 96,900 & 743,800 & 105,700 \\
\hline $\mathrm{N}$ & 93 & 23 & 70 & 7.7 & 0 & 0 & 17,600 & 336,700 & 182,300 & 536,600 & 97,800 & 743,800 & 109,400 \\
\hline High P & 123 & 10 & 113 & 3.5 & 30 & 5,100 & 24,100 & 334,400 & 186,600 & 545,000 & 101,800 & 743,800 & 97,000 \\
\hline Low P & 165 & 10 & 155 & 2.2 & 72 & 12,300 & 36,400 & 321,700 & 194,000 & 552,100 & 110,100 & 743,800 & 81,600 \\
\hline \multicolumn{14}{|l|}{ Large } \\
\hline Baseline & 150 & 46 & 104 & 5.4 & 0 & 0 & 45,900 & 406,600 & 346,200 & 798,700 & 324,700 & $1,383,400$ & 260,000 \\
\hline $\mathrm{N}$ & 150 & 74 & 75 & 7.7 & 0 & 0 & 30,000 & 418,400 & 350,400 & 798,800 & 324,500 & $1,383,400$ & 260,000 \\
\hline High P & 181 & 20 & 162 & 3.5 & 32 & 5,400 & 29,500 & 428,300 & 346,400 & 804,200 & 330,600 & $1,383,400$ & 248,600 \\
\hline Low $\mathrm{P}$ & 267 & 20 & 247 & 2.2 & 117 & 20,200 & 54,400 & 398,300 & 362,100 & 814,900 & 346,100 & $1,383,400$ & 222,400 \\
\hline
\end{tabular}

${ }^{\mathrm{a}}$ Dollar values have been rounded off to nearest hundreds.

${ }^{\mathrm{b}} \mathrm{S}$ cenarios with higher net returns than baseline value indicate net financial benefit relative to the baseline, and vice versa.

such situations. These coefficients represent the unit cost of pollutant reduction, for example, the unit cost of $\mathrm{P}$ load reduction.

Model simulation results were used to obtain cost-effectiveness coefficients for $\mathrm{P}$ load reduction as $-\$ 69, \$ 70$, and $\$ 140$ per $\mathrm{kg}$ of total $\mathrm{P}$ load reduced for the $\mathrm{N}$, High $\mathrm{P}$, and Low $\mathrm{P}$ scenarios. That is, for every $\mathrm{kg}$ of $\mathrm{P}$ reduced, producers would save $\$ 69$ if the $\mathrm{N}$ scenario is used, they would lose $\$ 70$ if the High $P$ alternative is in place, and they would incur a $\$ 140$ cost if the Low P option is used. These results do not mean, however, that the $\mathrm{N}$ scenario is necessarily the "best" alternative. It means that within limits of acceptable error, if no more than $12 \%$ reduction in aggregate $P$ loads at the watershed level is desired, the $\mathrm{N}$ scenario might be the most reasonable option because it achieves a roughly $12 \%$ reduction in aggregate $\mathrm{P}$ loads and producers obtain a profit increase, a win-win situation. However, the $\mathrm{N}$ scenario will not accomplish environmental objectives, if a $P$ load reduction target much greater than $12 \%$ is desired. It may be useful in some cases to target different scenarios to various producers, depending on spatial variability in economic and environmental impact potential, as other studies have also shown (e.g. Carpentier et al. 1998, VanDyke et al. 1999).

\section{Summary and Conclusions}

Many watersheds draining areas of intensive livestock farming have experienced varying degrees of water quality impairment due to nutrient enrichment from manure and commercial fertilizer applications. In the Lake Fork Reservoir Watershed (LFRW) of Texas, water quality measurements taken as part of a Hydrologic Unit Area project indicated elevated levels of $\mathrm{N}$ and $\mathrm{P}$ in tributary streams. Upland areas draining into the lake are predominantly characterized by dairy and beef cattle grazing operations that also apply commercial fertilizer on pasture. The Hydrologic Unit Area project indicated that highly intensive stocking of cattle on continuously grazed pasture may be partly responsible for excessive nitrogen and phosphorus loads to the lake and that appropriate stocking density management could reduce nutrient losses from dairy pasture. In this paper, results of computer model simulations performed to evaluate pasture nutrient management alternatives for the watershed were presented.

Pasture stocking densities were adjusted to conform to forage nutrient uptake requirements. In addition, commercial fertilizer rates on pasture were modified so that the combined rate of manure and commercial fertilizer nutrients applied to pastures was consistent with forage needs. Computer simulations using a comprehen- sive suite of models indicated that appropriate pasture nutrient management does have potential for nutrient loss reduction, particularly for phosphorus, which is typically the nutrient of primary concern regarding eutrophication of lakes. Economic results indicated varying impacts across dairy sizes and across the N, High P, and Low P pasture nutrient management alternatives. Whereas the nitrogen-based option would entail slight profit increases to producers (an aggregate profit increase of 3\%), the Pbased rates would result in moderate to significant cost increases (from 6 to $18 \%$ decline in profits on aggregate).

The choice of which alternative to use in a given situation depends on how much nutrient reduction is required. For instance, if total $\mathrm{P}$ loss reduction is the desired objective, the least costly alternative in this case is also the least effective. Within a performance-based water quality management program, a portfolio of options might be the best approach, with latitude for producers to choose which options best suit their operations.

\section{Literature Cited}

Arnold, J.G., R. Srinivasan, R.S. Muttiah, and J. R. Williams. 1998. Large area hydrologic modeling and assessment; Part I: model development. J. Amer. Water Res. Assoc. 34(1):73-89. 
ASAE. 1995. American Society of Agricultural Engineers. Manure production and characteristics. ASAE Data: ASAE D384.1 AFPC.

Bailey, K.L. and D.W. Riggs. 1996. A National Pilot Project: Livestock and the Environment - Nutrient Budget Analysis for the Lake Fork Reservoir Watershed. Project Report PR9608. Texas Instit. Appl. Environ.Res., Tarleton State Univ., Stephenville, Tex.

Belsky, A.J., A. Matzke, and S. Uselman. 1999. Survey of livestock influences on stream and riparian ecosystems in the western United States. J. Soil Water Conserv. First Quarter 1999:419-431.

Bottcher, AB., T.K. Tremwel, and K.L. Campbell. 1995. Best management practices for water quality improvement in the Lake Okeechobee watershed. Ecol. Eng. 5(1995):341-356.

Brooke, A., D. Kendrick, and A. Meeraus. 1992. GAMS: A User's Guide, Release 2.25 Washington, D.C.: World Bank.

Carpentier, C.L., D.J. Bosch, and S.S. Batie. 1998. Using spatial information to reduce costs of controlling agricultural nonpoint source pollution. Agr. Resource Econ. Rev. April 1998:72-84.

Correll, D.L. 1996. Environmental impacts of pasture systems on surface water quality. In: Nutrient Cycling in Forage Systems (R.E. Joost and C.A. Roberts, Ed.). Potash \& Phosphate Inst. and the Found. Agron. Res., Manhattan, Kans.

Dietz, FJ. and N. J.P. Hoogervorst. 1991. Towards a sustainable and efficient use of manure in agriculture: the Dutch case. Environ. Resource Econ. 1:313-332.

Ewer, S. and N. Easterling. 1998. Lake Fork Reservoir Watershed and Running Creek Sub-Watershed Geographic Information System Data Report. Report WP9805. Texas Inst. Appl. Environ. Res., Tarleton State Univ., Stephenville, Tex.

Flowers, J.D., J.R. Williams, and L.M. Hauck. 1996. NPP Integrated Modeling System: Calibration of the APEX Model for Dairy Waste Application Fields in Erath County, Texas. PR 96-07, Texas Inst Appl. Environ. Res., Tarleton State Univ., Stephenville, Tex.
Flowers, J.D., E. Osei, L.M. Hauck, P.W. Gassman, and A.M.S. McFarland. 1998 Livestock and the environment, a national pilot project: manure nutrient application rates and other assumptions underlying APEX runs. TIAER Information Bull. 98-03. Texas Inst. Appl. Environ. Res., Tarleton State Univ., Stephenville, Tex.

Hamilton, C.M. and J.T. Sims. 1995. Nitrogen and phosphorus availability in enriched, pelletized poultry litters. J. Sustainable Agr. 5(3):115-132.

Jones, R., L. Frarey, A. Bouzaher, S. Johnson, and S. Neibergs. 1993. Livestock and the Environment: A National Pilot Project; Detailed Problem Statement. Texas Inst. Appl Environ. Res. Stephenville, Tex. 1993.

LFCHUA 1995. Lake Fork Creek Hydrologic Unit Area Project. Ann. Project Rep. Fiscal Year 1995.

McDonald, R. 1995. Hopkins County Dairy Profile. Prepared for: Texas Inst. for Appl. Environ. Res., Stephenville, Tex, September 1995.

McFarland, A.M.S. and L.M. Hauck. 1999. Relating agricultural land uses to in-stream stormwater quality. J. Environ. Qual. 28(3):836-844.

McNitt, J., R. Jones, E. Osei, L. Hauck, and H. Jones. 1999. Livestock and the Environment: precedents for runoff policy policy option-CEEOT-LP. Report PR9909. Texas Inst. Appl. Environ. Res., Tarleton State Univ., Stephenville, Tex

Office of the State Chemist. 1996. Annual Report on Commercial Fertilizers. Texas Feed and Fertilizer Control Service, 1981-1995.

Osei, E., P. Gassman, and A. Saleh. 2000a. Livestock and the Environment: a national pilot project; Economic and environmental modeling using CEEOT. Report PR0002. Texas Inst. Appl. Environ. Res., Tarleton State Univ., Stephenville, Tex.

Osei, E., P. W. Gassman, R. D. Jones, S. J. Pratt, L. M. Hauck, L. J. Beran, W. D. Rosenthal, and J. R. Williams. 2000b. Economic and environmental impacts of alternative practices on dairy farms in an agricultural watershed. J. Soil Water Conserv. 55 (4):466-472.
Pratt, S., R. Jones, and C.A. Jones, 1997. Livestock and the environment: Expanding the focus: Policy options: CEEOT-LP, Texas Inst. Appl. Environ. Res., Tarleton State Univ., Stephenville, Tex.

Saleh A., J. G. Arnold, P. W. Gassman, L. M. Hauck, W. D. Rosenthal, J. R. Williams, and A.M.S. McFarland. 2000. Application of SWAT for the Upper North Bosque River Watershed. Trans. ASAE 45(3):1077-1087.

TNRCC. Various years. Dairy waste management plans. On file. Texas Nat. Resource Conserv. Com. Austin, Tex.

USDA. 1979. Animal waste utilization on cropland and pastureland: a manual for evaluating agronomic and environmental effects. USDA Utiliz. Res. Rep. No. 6. Sci. and Ed. Admin., USDA, Washington, D.C.

VanDyke, L.S., D.J. Bosch, and J.W. Pease. 1999. Impacts of within-farm soil variability on nitrogen pollution control costs. J. Agr. Appl Econ.. 31 (April 1999): 149-159.

Warrick, J. and S. Leavenworth. 1996 (March 9). Who will rescue the ravaged river? The News \& Observer. Raleigh, N.C.

Williams, J.R. 1990. The erosion productivity impact calculator (EPIC) model: a case history. Philosoph. Trans. of the Royal Soc. of London: Series B 329:421-428.

Williams, J.R. 1995. The EPIC model. In: Computer Models of Watershed Hydrology, V.P. Singh, ed, ch. 25, 909-1000. Highlands Ranch, Colo: Water Resour Publ.

Williams, J.R., J.G. Arnold, and R. Srinivasan. 2000. The APEX Model. BRC Report No. 00-06, Blacklands Res. Center, Texas Agr. Exp. Stat., Texas Agr. Exten. Serv., Texas A\&M Univ. System, Temple, Tex.

Williams, J.R., C.A. Jones, P.W. Gassman, and L.M. Hauck. 1995. Simulation of animal waste management with APEX. In: Innovations and New Horizons in Livestock and Poultry Manure Management, 22-26. Austin, Tex., 6-7 September. 